\section{HALANDÓSÁG BECSLÉSE AZ EGÉSZSÉGÁLLAPOT FÜGGVÉNY SEGÍTSÉGÉVEL}

Hegel Patrik (NN Biztositó Zrt., Széchenyi István Egyetem), EFOP-3.6.2-16-2017-00015 projekt keretében hegel.patrik@gmail.com

\section{ÖSSZEFOGLALÓ}

Az utóbbi két évszázad folyamán a Föld lakosságának halandósága fokozatosan csökken, aminek eredményeként a várható élettartam körülbelül kétszeresére nőtt. Az emberek növekvő élethosszának köszönhetően bekövetkező gazdasági és szociális hatások vizsgálata több területen is kiemelkedő fontosságú. Például a nyugdíjrendszerrel, nyugdíjbiztosításokkal és életbiztosításokkal kapcsolatos számítások jelentős része halálozási arányszámokon alapul. Ezeknek az intézményeknek elengedhetetlen a hosszú élet kockázatát megfelelően felmérni és kezelni, hiszen a lakosság egyre nagyobb hányada él kiemelkedően magas, akár 110 év feletti korig. A cikkben egy olyan halandósági modellt mutatok be, amely képes egy lakosság halandóságának dinamikáját jól leírni és előre jelezni múltbeli adatok alapján. A publikáció alapjául az a BCE-ELTE közös Biztosítási és Pénzügyi Matematika mesterszakán írt szakdolgozatom és a Széchenyi István Egyetemen végzett EFOP-3.6.2-16-2017-00015 számú projektmunka szolgált. A szakdolgozat alapján a szerzőnek ítélte a MAT a Biztosításmatematika Ifú Mestere díjat.

\section{SUMMARY}

Over the last two centuries, the mortality of Earth's population has gradually declined and as a result life expectancy has roughly doubled. Examining the economic and social impacts associated with people's increasing life expectancy is of paramount importance in multiple areas. For example, several calculations related to the pension system, pension insurance and life insurance are based on mortality rates. It is essential for these institutions to assess and manage longevity risks properly, as increasing proportion of the population lives until an exceptionally high age. In this article, I present a mortality model that is able to well describe and predict the dynamics of a population's mortality based on past data. The publication is based on my thesis written in the Master's program 'Actuarial and Financial Mathematics' of Eötvös Loránd University and the project work at Széchenyi István University (EFOP-3.6.2-16-2017-00015). Based on the dissertation the MAT awarded the author the Young Master of Acuarial Award.
Kulcsszavak: egészségi állapot, halandósági modell, hosszú élet kockázata Key words: health, mortality model, longevity risk

JEL: C53, G22, J11, J32

DOI: $10.18530 /$ BK.2021.1-2.30

http://dx.doi.org/10.18530/BK.2021.1-2.30

\section{Várható halandóság becslése}

Az élet- és nyugdíjbiztosítások esetén központi téma a lakosság várható halandóságának becslése és előrejelzése. A biztosítók a megfelelő halandósági ráták használatával egyrészt a lehető legpontosabb díjkalkulációra, továbbá a jövőbeli várható kötelezettségeik felmérésére törekednek. A cikk első részében egy kézenfekvő becslést végzünk az elmúlt évek halandósági adatai alapján több ország mortalitásának alakulására. Feltételezve, hogy valamely lakosság esetén rendelkezésünkre állnak adatok az elmúlt $n$ évből az elhunytak és megfigyeltek létszámára 1-100 éves korig minden életkorra, vezessük be az alábbi jelöléseket: jelölje rendre $N^{i}$ és $D^{\mathrm{i}}$ a $j$-edik évben és $i$-edik életkorban a megfigyeltek és a halottak számát. Megjegyzendő, hogy $N_{j}^{i}$ nem feltétlen egész szám, ugyanis ha egy $t$ éves személy születésnapja év közben lesz, akkor az év első törtrészét $N^{t}$-hez, a másodikat $N_{t+1}^{j}$-hez számoljuk. A tényleges halálozási rátákat egy adott életkorra és évre az alábbi hányadosaként kaphatjuk meg:

$$
r_{i}^{j}=\frac{D_{i}^{j}}{N_{i}^{j}}
$$

Ezek alapján határozzuk meg $n$ évre az átlagos halandósági rátákat koronként, és azok segítségével jelezzük elöre a következő évek halandóságát.

$$
\text { Tehát legyen } \quad \bar{r}_{i}=\frac{\sum_{j=1}^{n} \frac{D_{i}^{j}}{N_{i}^{j}}}{n} .
$$

Ekkor $N_{i}$ “darab” $i$ éves megfigyelt személy esetén az elhunytak becsült száma:

$$
\widehat{D}_{i}=\bar{r}_{i} \times N_{i} \text {. }
$$

A valós adatokon való becslésnél az átlagos ráta számolására 10 év adatait tekintettük. Az adatok forrása a Human Mortality Database ${ }^{[8]}$ volt, ahonnan a Magyarországra, Svédországra, az USA-ra, Japánra és az Egyesült Királyságra vonatkozó adatokat kértük le a 2006-2015 közti évekre. Az elörejelzéseket a 2016-os és 2017-es évre végeztük (illetve ahol rendelkezésre állt 2018-as adat, ott arra is). A 10 éves átlagos rátával előre jelezve a 
következő évek halandóságát, azt tapasztaljuk, hogy jellemzően felülbecsüljük az elhunytak valós számát. Az 1. ábrán az elhunytak becsült és valós számát szemléltetjük különböző országok esetén:

\section{1.ábra: Elhunytak becsült és valós száma országonként}

Elörejelzés - Magyarország, 2016 - Total

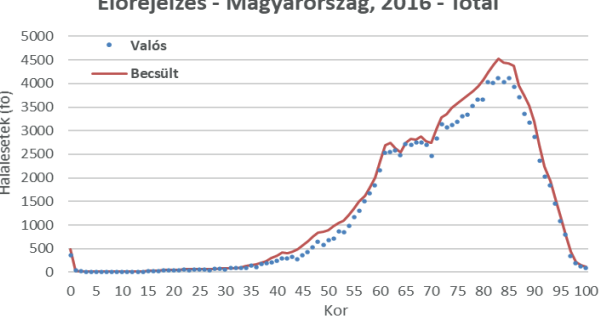

Elörejelzés - USA, 2016 - Férfi

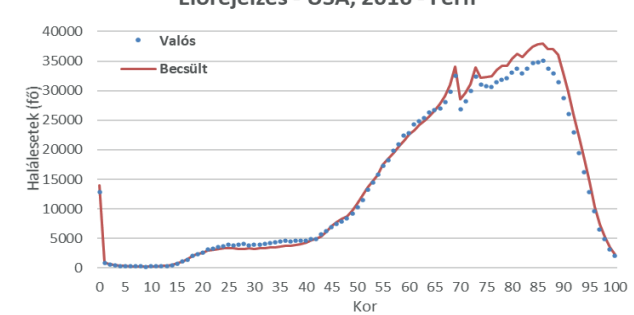

Elörrejelzés - USA, 2016 - Nö́t

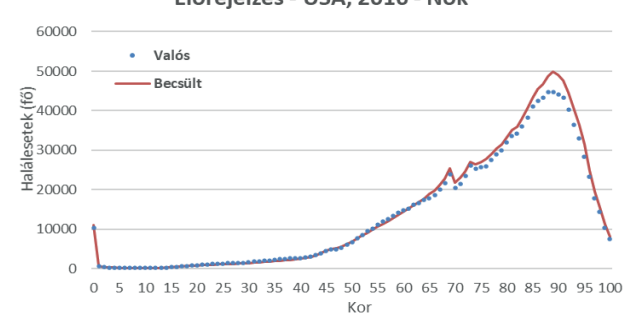

Elörejelzés - Egyesült Királyság, 2016 - Total

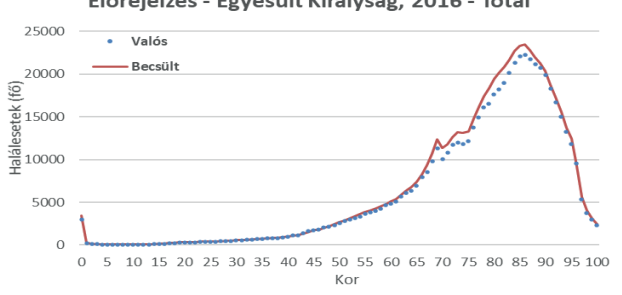

Forrás: saját készités
Elörejelzés - Magyarország, 2017 - Total

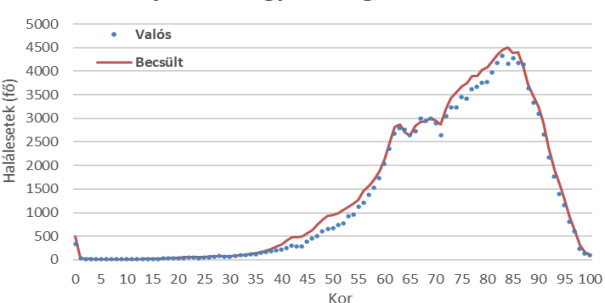

Elörejelzés - USA, 2017 - Férfi

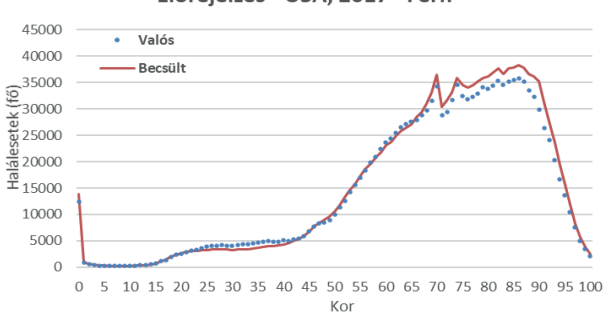

Elörejejzés - USA, 2017 - Nök

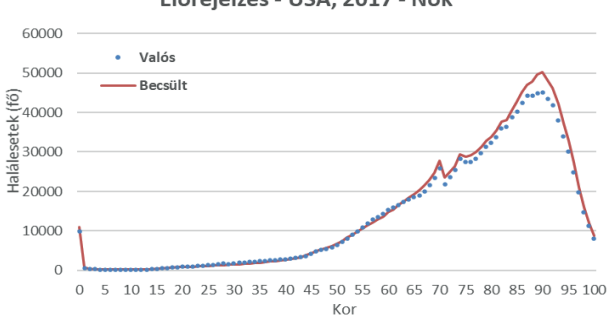

A túlbecslés magyarázata a halandóság javulása lehet: arra számítunk, hogy a vizsgált évek, illetve évtized alatt az egészségügy általános javulása, a lakosság tudatosabb és egészségesebb életvitele jobb mortalitást eredményez, bármely országot vizsgáljuk. Az egyetlen kivétel az USA középkorú lakossága, ahol nem becsültük fölé a halandóságot. Ennek oka lehet, hogy a 2010-es évek eleje óta az Egyesült Államokban és az Egyesült Királyságban is megállt vagy lelassult a halandóság javulása, különösen a munkásréteg körében ([10][11] [14]). Az előbbiekben alkalmazott egyszerű becslés egyik hibája az, hogy a mortalitás időbeli alakulását gyakorlatilag nem tudja kezelni és elöre jelezni. Továbbá elképzelhető az is, hogy egy-egy évben kiugrásszerủen változnak a halandósági mutatói egy országnak. Erre jó példa lehet akár egy a megszokottnál súlyosabb járvány (például a Covid 19 napjainkban) vagy a nép egészségügyét és egészségi helyzetét érintő kormányzati intézkedés. Ha egy ilyen évet is számításba veszünk, akkor az a figyelembe vett évek számától függően torzíthat az átlagos halandósági ráták meghatározásakor, ezáltal pontatlan becslésre vezetve. Felmerül tehát az igény egy olyan halandósági modell alkalmazására, amely a mortalitást és annak több év távlatában történő alakulását hatékonyabban kezeli. Az ilyen célokra alkalmazott modellek közül megemlítendőek a Lee-Carter [1992] és a Cairns-Blake-Dowd [2006] modellek. A szakdolgozat további fejezeteiben azonban egy ezektől különböző modell kerül bemutatásra és kiegészítésre, amely alkalmas a halandóságnak és változásának leírására.

\section{Egészségállapot függvény}

\section{Az egészségi állapot alakulásának modellezése}

A mortalitással szorosan összefüggő fogalom az egészségi állapot, ugyanakkor ennek mérése ritkábban alkalmazott eszköz a biztosításban, az egészségtudományokban és a demográfiában. Ennek oka az lehet, hogy a mortalitás egy jól meghatározott fogalom, amely precízen számolható adott korcsoportokra az elhunytak és az élők számából. Ezzel szemben a lakosság vagy akár az egyén egészségi állapotának számszerü meghatározása nem mérhető ennyire egyszerűen. Bár a mindennapi köznyelv része, a felmérésekkel és kérdőívekkel szerzett adatok bizonytalansága és inkonzisztenciája nem igazán ad lehetőséget modellezésre az egyén szintjén. Ugyanakkor ez nem is szükségszerü, hiszen most az elsődleges célunk a lakosság egészére definiálni és meghatározni egy aggregált egészségi állapotot. A cikkben egy lehetséges modellt és annak módosítását, továbbfejlesztését mutatjuk be a halandóság becslésére az egészségi állapot használatával. Egy személy élete során az egészségi állapota időben jellemzően romlik, és gyakori, hirtelen változások vannak benne. Emiatt matematikailag formalizálva tekintsük egy időben folytonos sztochasztikus folyamatnak, amelyet jelöljön $S=(S(t), t \geq 0)$ az idő függvényében. A halandóság modellezése szempontjából azt feltételezzük, hogy a halál akkor következik be, ha az egészségi állapot kellően nagy mértékben lecsökken, ellenben ha az magasabb szinten marad, akkor életben van az egyén. A halál bekövetkeztének idejét definiáljuk úgy, hogy az a pillanat, amikor az 
egészségállapot függvény egy bizonyos a szint alá csökken elöször. Tehát tulajdonképpen a sztochasztikus folyamat egy bizonyos szint elérési ideje. Tegyük fel, hogy születéskor az egyén $S(0)$ "kezdeti értékkel" kezd és az évek során az egészségi állapotot leíró folyamat fejlődése megadható a következő sztochasztikus differenciál egyenlettel:

\section{$d S(t)=\mu(S, t) d t+\sigma(S, t) d W(t)$}

Janssen és Skiadas modelljében ${ }^{[1]}$ a következő egyszerüsítéseket választja:

$$
\mu(S, t)=\mu(t), \sigma(S, t)=\sigma(t)
$$

ahol tehát $S(t)$ a sztochasztikus folyamat értéke a $t$ idő függvényében, $\mu(t)$ a drift együttható, $\sigma(t)$ a szórásparaméter és $W(t)$ a standard Wiener-folyamat. Vagyis a folyamat egy Ito-folyamat, adott kezdeti értékkel:

$$
S(t)=S(0)+\int_{0}^{t} \mu(s) d s+\int_{0}^{t} \sigma(s) d W(s)
$$

Az említett egyszerüsítések magukkal vonnak nem kézenfekvő jellegzetességeket is. Például azt várnánk, hogy egy súlyosabb betegség után változékonyabb az egészségállapot, ugyanis a beteg kigyógyulhat, de akár további szövődményei is lehetnek. Vagyis a szórásparaméter az egészségi szinttől is függhetne. Ahogy azonban a későbbiekben látni fogjuk, így is sikerült pontos illeszkedést elérni a modellel.

\section{A haláleset bekövetkezési idejének eloszlása}

A következő részben egy közelítést adunk a haláleset bekövetkezési idejének eloszlására. Továbbá definiálásra kerül az "egészségállapot függvény", amely populációs szinten hivatott jellemezni az egészségi állapotot. Ehhez az $S$-hez tartozó "átmenet" eloszlásfüggvényt jelölje $P$, azaz

$$
P(x, t ; z, \tau)=P[S(t) \leq x \mid S(\tau)=z],
$$

ahol $\tau \leq t, x, z>0$. Jelölje az átmeneti sűrűségfüggvényt (bizonyos regularitási feltételek mellett ilyen létezik): $\mathrm{p}(\mathrm{x}, \mathrm{t} ; \mathrm{z}, \tau)=\partial / \partial \mathrm{x} \mathrm{P}(\mathrm{x}, \mathrm{t} ; \mathrm{z}, \tau)$. Erre teljesül a Chapman-Kolmogorov egyenlet:

$$
p\left(S_{0}, t_{0}, S, t\right)=\int_{-\infty}^{\infty} p\left(S_{0}, t_{0}, y, s\right) p(y, s, S(t), t) d y,
$$

ahol legyen $p\left(S_{0}, t ; S(t), t\right)=\delta\left(S(t)-S_{0}\right)$ és $\delta$ a Dirac-delta függvény. A Chapman-Kolmogorov egyenlőség azt fogja meg, hogy a kiinduló $t_{0}$ időből és $S_{0}$ értékből a folyamat a $t, S_{t}$ kettősbe a lehetséges $y$ értékek egyikén keresztül kerül [5]. Folytonos idejü sztochasztikus folyamatok esetén a Chapman-Kolmogorov egyenlet a Fokker-Planck egyenletre redukálódik ([6]):

$$
\frac{\partial p(S, t)}{\partial t}=-\mu(t) \frac{\partial p(S, t)}{\partial S}+\frac{1}{2}[\sigma(t)]^{2} \frac{\partial p(S, t)}{\partial S^{2}} .
$$

Ahhoz, hogy az egyenletnek egyetlen megoldása legyen, a következő határfeltételeket használjuk:

$$
\begin{aligned}
& \mathrm{p}\left(\mathrm{S}(\mathrm{t}), \mathrm{t}_{0} ; \mathrm{S}_{0}, \mathrm{t}_{0}\right)=\delta\left(\mathrm{S}(\mathrm{t})-\mathrm{S}_{0}\right) \\
& \frac{\partial \mathrm{p}\left(\mathrm{S}(\mathrm{t}), \mathrm{t}_{0} ; \mathrm{S}_{0}, \mathrm{t}\right)}{\partial \mathrm{S}(t)} \rightarrow 0, \text { ha } \mathrm{S}(\mathrm{t}) \rightarrow \pm \infty
\end{aligned}
$$

Az egyenlet megoldása karakterisztikus függvények segítségével történik, azaz legyen

$$
\Phi(s, t)=\int_{-\infty}^{\infty} p\left(S, t ; S_{0}, t_{0}\right) \exp (i s S) d S
$$

A szakdolgozatban [13] megtalálható a részletes bizonyítás, amit jelen cikkben kihagyunk. Röviden összefoglalva, az előző karakterisztikus függvényről parciális integrálás segítségével megmutatható, hogy egy normális eloszláshoz tartozik. Mégpedig a normális eloszlás várható értéke $S_{0}+\int_{t_{0}}^{t} i s \mu(u) d u$, szórása $\int_{t_{0}}^{t} \sigma(u)^{2} d u$. Tehát a szóban forgó egyenlet megoldása:

$$
p\left(S, t ; S_{0}, t_{0}\right)=\frac{1}{\left[2 \pi \int_{t_{0}}^{t} \sigma(s)^{2} d s\right]^{\frac{1}{2}}} \exp \left[-\frac{\left[S-S_{0}-\int_{t_{0}}^{t} \mu(s) d s\right]^{2}}{2 \int_{t_{0}}^{t} \sigma(s)^{2} d s}\right]
$$

Ennek az átmeneti sűrűségfüggvénynek a segítségével határozzuk meg az eredeti célunkat, vagyis a haláleset idejének eloszlását. Ehhez azonban további egyszerűsítésként tegyük fel előbb, hogy a folyamat szórásparamétere konstans, azaz $\sigma(t)=\sigma$. Ekkor az átmeneti sűrűségfüggvény a következőképpen írható le:

$$
p\left(S, t ; S_{0}, t_{0}\right)=\frac{1}{\left[2 \pi \sigma^{2}\left(t-t_{0}\right)\right]^{\frac{1}{2}}} \exp \left[-\frac{\left[S-S_{0}-\int_{t_{0}}^{t} \mu(s) d s\right]^{2}}{2 \sigma^{2}\left(t-t_{0}\right)}\right]
$$

A halál bekövetkeztét az $S$ folyamat egy bizonyos a szintelérési idejeként definiáltuk, amit jelöljön $T$, azaz $T=\inf (t: S(t) \leq \alpha)$. Azaz a feladat $T$ sürüségfüggvényének meghatározása $t_{0} \leq t$-re:

$$
g\left(\alpha, t ; S_{0}, t_{0}\right)=\frac{\partial}{\partial t} \operatorname{Pr}\{T \leq t\}
$$


Az adott $S_{0}$ kiindulási pontból az $\alpha$ szint elérési idejének sűrűségfüggvénye lineáris drift és konstans szórás esetén:

$$
g\left(\alpha, t ; S_{0}, t_{0}\right)=\frac{\left|\alpha-S_{0}\right|}{t-t_{0}} p\left(S, t ; S_{0}, t_{0}\right)
$$

Janssen és Skiadas ennek segítségével közelíti az elérési idő sűrűségfüggvényét, így behelyettesítve az átmeneti sűrűségfüggvényt az előbbi kifejezésbe:

$$
g\left(\alpha, t ; S_{0}, t_{0}\right)=\frac{\left|\alpha-S_{0}\right|}{\left[2 \pi \sigma^{2}\left(t-t_{0}\right)^{3}\right]^{\frac{1}{2}}} \exp \left[-\frac{\left[\alpha-S_{0}-\int_{t_{0}}^{t} \mu(s) d s\right]^{2}}{2 \sigma^{2}\left(t-t_{0}\right)}\right]
$$

$\mathrm{Az} S$ sztochasztikus folyamat az egészségi állapotot az egyén szintjén jellemzi. Ahhoz, hogy a teljes populáció egészére jellemző mennyiséget kapjunk, ezeknek egy aggregációjára van szükségünk. Jelöljük ezt a folyamatot $H$-val, és definiáljuk az $S$ folyamat várható értékeként minden $t$ időpontban:

$$
H(t)=E(S(t))=\mathrm{S}_{0}+\int_{t_{0}}^{t} \mu(s) d s
$$

Ezt a $H(t)$ függvényt nevezzük "egészségállapot függvénynek". Egy másik közelítési módszer, amit használnak, az úgynevezett "tangent approximation". Eszerint $S_{0}$ kiindulási érték, $\alpha=0$ elérési szint és $t_{0}=0$ esetén az elérési idő sűrűségfügg vényét a következőképpen közelítjük:

$$
\begin{gathered}
g\left(0, t ; S_{0}, 0\right)=\frac{\left|H(t)-t H^{\prime}(t)\right|}{t} p\left(0, t ; S_{0}, 0\right)= \\
=\frac{\left|H(t)-t H^{\prime}(t)\right|}{\sqrt{2 \pi \sigma^{2} t^{3}}} \exp \left(-\frac{H(t)^{2}}{2 \sigma^{2} t}\right)
\end{gathered}
$$

\section{A Skiadas-féle modell}

\section{Az egészségállapot függvény paraméterezése}

Az előző részben bevezetésre került az egyén egészségi állapotának alakulását leíró $S$ sztochasztikus folyamat a következőképpen:

$$
d S(t)=\mu(t) d t+\sigma d W(t)
$$

ahol $\mu$ és $\sigma$ fejezi ki az infinitezimális átlagos változását és varianciáját az egészségállapotnak.
A $H(t)$ egészségállapot függvényt az $S$ folyamat várható értékeként definiáltuk:

$$
H(t)=E S(t)=S(0)+\int_{t_{0}}^{t} \mu(s) d s
$$

Az egészségfüggvény $H(t)$ és $\mu(t)$ közti kapcsolat másképp felírva:

$$
\mu(t)=\frac{\partial H(t)}{\partial t}
$$

Vagyis ha $\mu(t)$ függvényt megadjuk analitikusan, akkor a $H(t)$ egyszerüen megkapható belőle. Azt feltételezzük, hogy az egészségállapot születés után jellemzően gyorsan javul, majd enyhül ez a javulás, végül egy bizonyos kor után az egészségi állapot elkezd elromlani. Ennek megfelelően $\mu(t)$-nek az emberi élettartam két elkülönülő időszakát kell jól jellemeznie. Az első időszakra vonatkozzon az $u=u(1 / \sqrt{t})$ függvény, amelynek gyorsan csökkenőnek és pozitívnak kell lennie az időben, utalva a születés utáni lassuló ütemű fejlődésre. A második időszakot leíró $v=v(t)$ függvény pedig az először fokozatosan javuló, majd romló egészségi állapotot kell megfogja a teljes élettartamra. Ezen meggondolások nyomán egy lehetséges parametrizálása $\mu(t)$-nek:

$$
\mu(t)=u\left(\frac{1}{\sqrt{t}}\right)+v(t)
$$

ahol

$$
u\left(\frac{1}{\sqrt{t}}\right)=\frac{1}{2} \frac{b_{1}}{\sqrt{(t)}}
$$

$$
v(t)=2 a_{1} t+3 a_{2} t^{2}+4 a_{3} t^{3}
$$

Tehát ezzel a közelítéssel élve és feltéve, hogy $t_{0}=1$ és $S_{0}=0$, kapjuk a következőt:

$$
H(t)=E[S(t)]=\int_{0}^{t} \mu(s) d s=a_{1} t^{2}+a_{2} t^{3}+a_{3} t^{4}+b_{1} \sqrt{t}-c
$$

ahol $c=a_{1}+a_{2}+a_{3}+b_{1}$. A 2. ábrán rögzített $a_{\text {és }} \alpha$ paraméterek mellett, különböző $b_{1}-\mathrm{k}$ esetén ábrázoltuk a $H(t)$ függvényt. Tetszőlegesen lettek megválasztva a paraméterek: $a_{1}=-10^{-2}, a_{2}=10^{-3}, a_{3}=-10^{-4}$ és $\alpha=-4.4$ 
2. ábra:

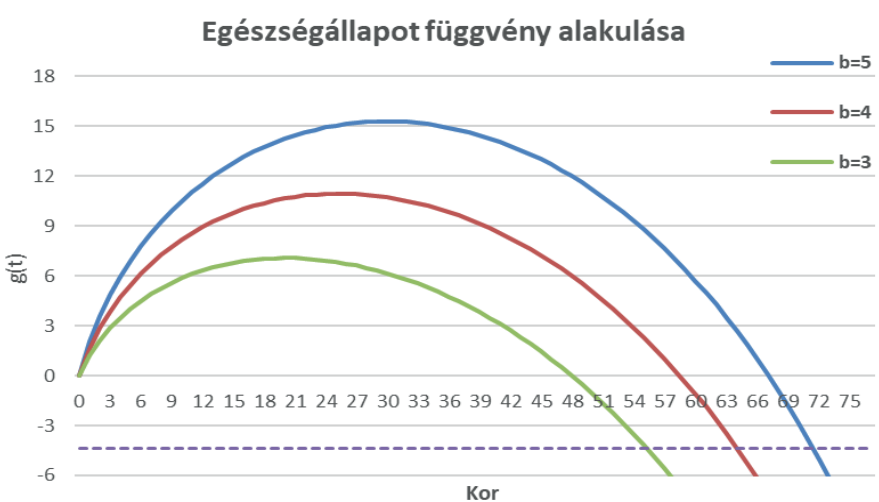

Forrás: saját készités

A 3. ábrán pedig a $b_{1}=5$ esetben $H(t)$ és $\mu(t)$ látható:

3. ábra:

\section{$H(t)$ és $\mu(t)$ alakulása}

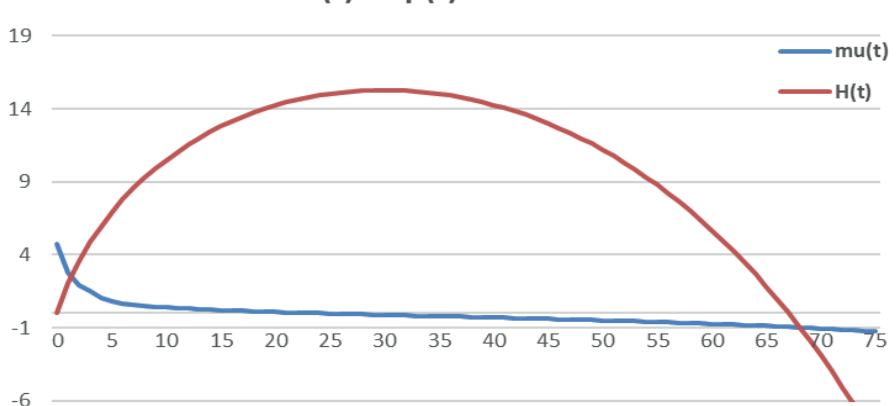

Kor

Forrás: saját készités

A halál idejének eloszlását megadó formulába behelyettesítve $H(t)$-t:

$$
g\left(0, t ; S_{0}, 0\right)=k \frac{|\alpha|}{\sqrt{2 \pi t^{3} \sigma^{2}}} \exp \left(-\frac{\left[\frac{\alpha+c}{\sqrt{t}}-\left(b_{1}+a_{1} t \sqrt{t}+a_{2} t^{2} \sqrt{t}+a_{3} t^{3} \sqrt{t}\right)\right]^{2}}{2 \sigma^{2}}\right)
$$

ahol $c=a_{1}+a_{2}+a_{3}+b_{1}$ továbbra is és $k$ egy normalizáló konstans, amely az alábbi formulából kapható meg:

$$
\int_{0}^{\infty} g(s) d s=1
$$

Látható, hogy ha minden paramétert elosztunk $\sigma$-val, akkor ugyanazt a kifejezést kapjuk a sűrűségfüggvényre, ezért feltehetjük, hogy $\sigma=1$. A 4. ábrán a korábban ábrázolt egészségfüggvényekhez tartozó sürüségfüggvényeket ábrázoltuk (csak a $b_{1}=4$ és $b_{1}=5$ eset):

4. ábra:

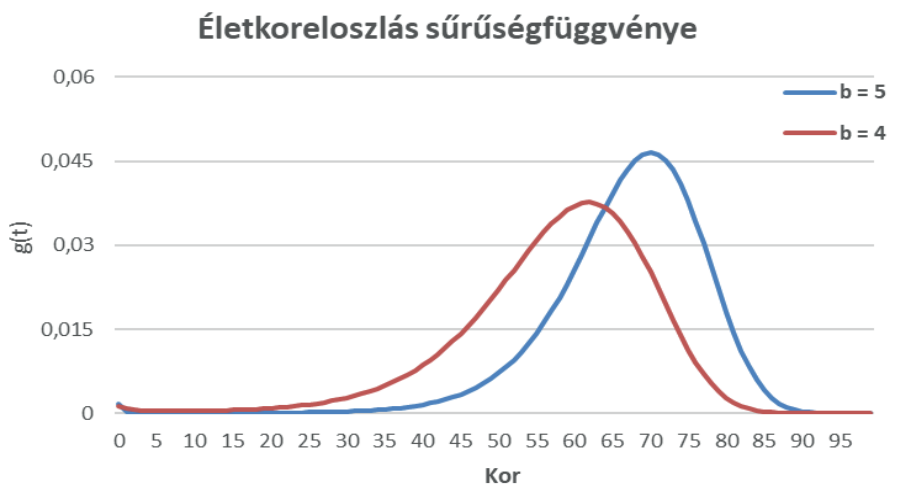

Forrás: saját készités

A cikk során a modell valós adatokra történő illesztése és a paraméterek meghatározása később lesz részletezve. Elöljáróban megemlíthető, hogy az illeszkedés pontos volt, azonban célunk, hogy csökkentsük a paraméterek számát. Ezáltal könnyebben össze lehetne hasonlítani más egyszerűbb modellekkel, amelyek paraméterszáma nem különbözik nagymértékben. Másfelől ez a modell kezeli a teljes emberi élettartamot, beleértve a csecsemőkori halandóságot is, amit az egyszerúbb modellek használatával jellemzően kevésbé lehet. Ezért bemutatjuk $H(t)$ egy másik lehetséges paraméterezését, amelyben a paraméterek száma már kevesebb lesz, ugyanakkor nem lesz alkalmas a fiatalkori egészségi állapot és mortalitás jellemzésére. Azt vehetjük észre, hogy a $H(t)$ korábbi paraméterezésénél a függvény csökkenését leginkább a nagyobb kitevős tagok befolyásolják, ezért egy pontos közelítés lehetne a következő paraméterezés:

$$
H(t)=c-(l t)^{b}
$$

ahol l,c és b pozitív paraméterek. A b paraméter pozitivitása garantálja, hogy $H(t)$ egy csökkenő függvény (és $b$-ben csökkenő). A c paraméter az egészségállapot függvény kiindulási szintje $t=0$-ban. A halál bekövetkeztére definiált a szintet tekinthetjük 0-nak, ugyanis ha $S(0)$-ból indulva $\alpha$-t kell elérni, akkor az ugyanaz, mintha a $c=\mid S(0)$ - $\alpha \mid$-ból indulva a 0 szintet kellene. Az így definiált egészségállapot függvénnyel kifejezve a haláleset eloszlásának sűrűségfüggvénye:

$$
g(0, t ; c, 0)=\frac{\left|c+(b-1)(l t)^{b}\right|}{\sqrt{2 \pi t^{3}}} \exp \left(-\frac{\left(c-(l t)^{b}\right)^{2}}{2 t}\right)
$$


Az 5-6. ábrák közül az elsőn az új paraméterezéssel felírt egészségállapot függvényeket ábrázoljuk különböző $b$ paraméterek esetén, rögzített $c$ és $l$ paraméter mellett ( $c=15$ és $l=0.03$ ). A másodikon pedig az ezekhez tartozó $g$ sürűségfüggvényei a 0 szint elérési idejének.

5. ábra:

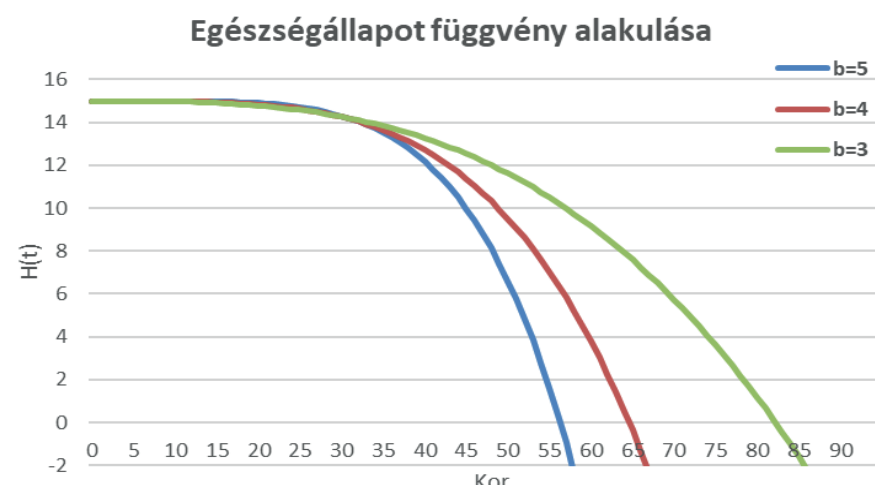

Forrás: saját készités

6. ábra:

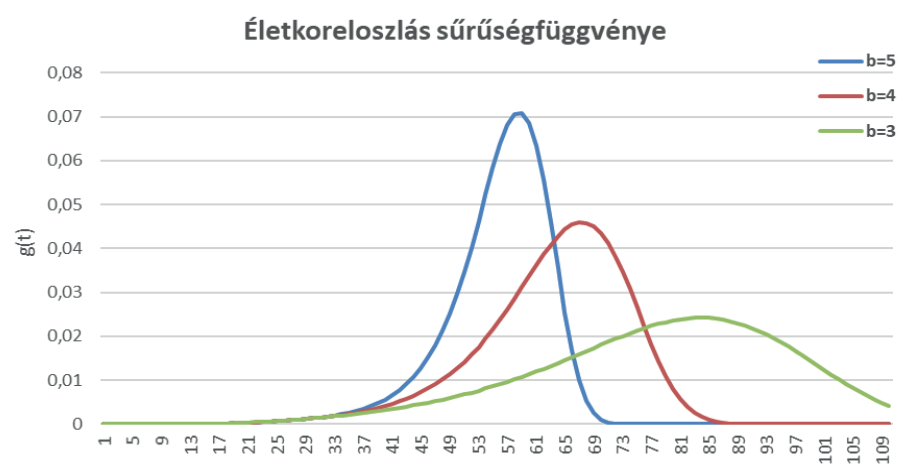

Forrás: saját készités

\section{Paraméterbecslés}

Több lehetséges paraméterezés után most rátérnénk a paraméterek becslésének lehetséges módszereire. Tegyük fel, hogy a rendelkezésünkre álló halandósági táblában szerepelnek minden életkorra (0-110 év), hogy hányan hunytak el, és mennyien voltak megfigyelve. Ebből számolható a haláleset bekövetkezési idejének tapasztalati eloszlása, amihez vezessük be a következő jelölést: $y_{x}=P(x \leq T<x+1)$, ahol $T$ az élettartamot jelöli.
Janssen és Skiadas a következőképpen becsüli ezek segítségével a paramétereket. A $j$ éves kori haláleset valószínűségét közelítsük úgy, hogy a g sürűségfüggvényt tekintsük állandónak az adott életkornak megfelelő szakaszon, így $P(x \leq T<x+1) \approx g(j)$. Ekkor pedig keressük azokat a paramétereket, amelyekre a tapasztalati és a becsült valószínűségek közti négyzetes eltérés minimális, azaz a második paraméterezést tekintve:

$$
\min \left(y_{j}-g(j)\right)^{2}=\min \left(y_{j}-\frac{\left|c+(b-1)(l t)^{b}\right|}{\sqrt{2 \pi t^{3}}} \exp \left(-\frac{\left(c-(l t)^{b}\right)^{2}}{2 t}\right)\right)^{2}
$$

Az optimális paraméterek meghatározása iteratív módszerrel történt. Egy másik lehetőség, hogy ha vannak megfigyeléseink a jéletkorban $l_{j}$ megfigyelt leélt évek számát és a $j$ életkorban meghaltak $d_{j}$ számát illetően, akkor maximum-likelihood becslést adunk a paraméterekre:

$$
L=\prod_{j=j_{o}}^{j_{\max }}\left(\begin{array}{c}
l_{j} \\
d_{j}
\end{array}\right) p_{j}^{d_{j}}\left(1-p_{j}\right)^{l_{j}-d_{j}}
$$

ahol $l_{j}$ a megfigyelt leélt évek száma a $j$-edik életkorban, $d_{j}$ a megfigyelt halálesetek száma a j-edik évben és $p$ a halálozási valószínűség a j-edik évben. A $p$. valószínűségek becslése viszont nem triviális, a több lehetséges számolás közül a legkevésbé számításigényeset szeretnénk alkalmazni. Tegyük fel, hogy $j$ az első vizsgált életkor (nem feltétlen célunk születéstől modellezni a halandóságot). Ekkor annak a valószínűsége, hogy $j_{0}$ évesen veszti valaki életét, közelíthető $g_{j_{0}}$ )-vel és a likelihood a következő formában is felírható:

$$
L=l_{j_{0}} !\left(\prod_{j=j_{0}}^{j_{\max }} \frac{g(j)^{d_{j}}}{d_{j} !}\right) \times \frac{\left(1-g\left(j_{0}\right)-\ldots-g\left(j_{\max }\right)\right)^{\left(l_{j_{0}}-d_{j_{0}}-\ldots-d_{\max }\right)}}{\left(l_{j_{0}}-d_{j_{0}}-\ldots-d_{j_{\max }}\right) !}
$$

A likelihoodban szereplő szorzó tag a jobb oldalon azokra vonatkozik, akik nem halnak meg $j_{\max }$ kor előtt, hanem tovább élnek. Ekkor logaritmálás után kapjuk a loglikelihood

$$
l=k o n s t+\sum_{j=j_{0}}^{J_{\max }} d_{j} \log (g(j))+\left(l_{j_{0}}-d_{j_{0}}-\ldots-d_{\max }\right) \log \left(1-g\left(j_{0}\right)-\ldots-g\left(j_{\max }\right)\right)
$$

függényt:

Ezt maximalizálva kaphatunk becsléseket a paraméterekre. A maximalizálás ebben az esetben is iteratív módszerekkel történhet.

\section{A modell illesztése valós adatokra}

A következőkben a brit lakosság 2000-es adatait használjuk, külön becsüljük a női és férfi halandóságot, és összehasonlítjuk azokat. Először tekintsük az első parametrizált egészségfüggvényt, azaz amikor

$$
H(t)=a_{1} t^{2}+a_{2} t^{3}+a_{3} t^{4}+b_{1} \sqrt{t-c}
$$


ahol $c=a_{1}+a_{2}+a_{3}+b_{1}$. Továbbá a paraméterek becslését most az előző fejezetben taglalt Skiadas és Janssen-féle négyzetes eltérés minimalizálásával tesszük meg. A 7-8. ábrákon látható a valós és a becsült eloszlás illeszkedése.

7. ábra:

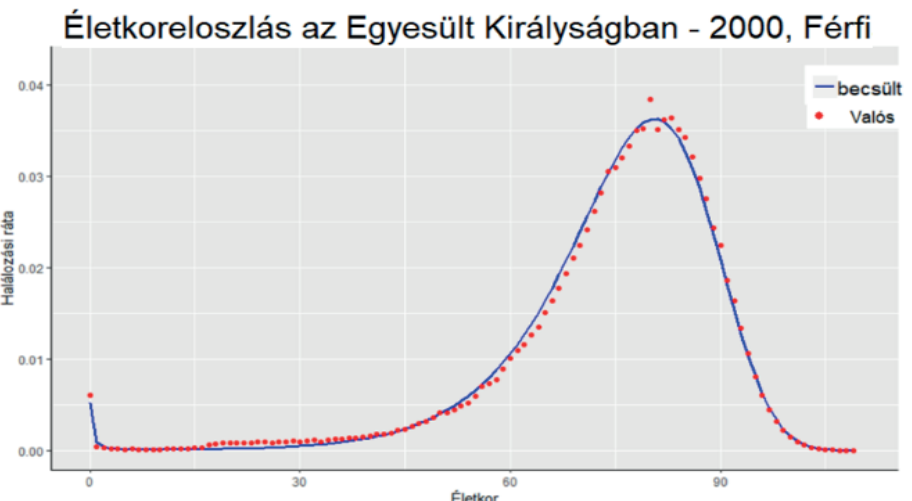

Forrás: saját készités

8. ábra:

Életkoreloszlás az Egyesült Királyságban - 2000, Nők

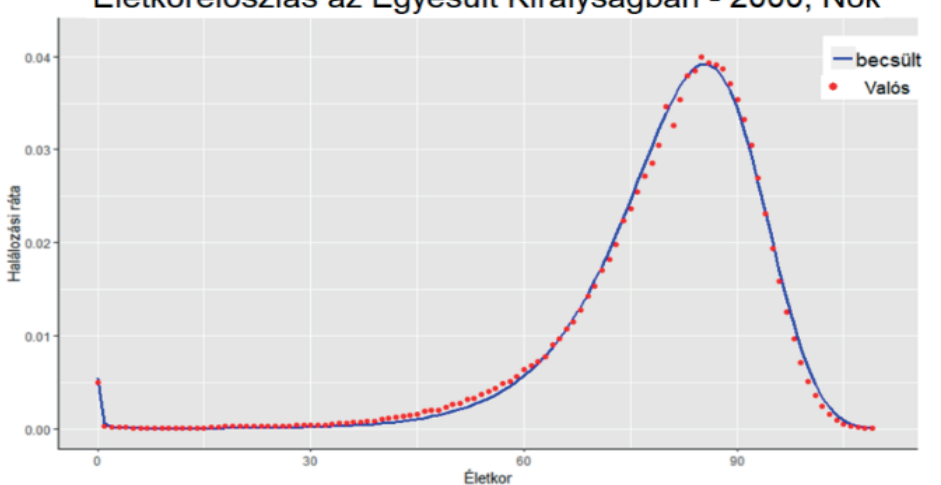

Forrás: saját készités

Észrevehető, hogy a modell képes kezelni a csecsemőkori halandóságot valamilyen szinten. Megjegyzendő, hogy a kapott paraméterek nagymértékben függtek az iteratív algoritmusnak megadott kiindulási értékektől. Előfordult olyan kifutás is, amikor az illesztés nem kezelte jól a csecsemőkori halandóságot. A nők halandósága köztudottan jobb a férfiakénál az európai országok tekintetében. Ezt a becsült eloszlásból is láthatjuk, hiszen a nők halandósága "jobbra tolódott" a férfiakéhoz képest. Ábrázolhatjuk a $H(t)$ egészségfüggvényt és a haláleset definiálásához használt a szintet a két esetben:
9. ábra:

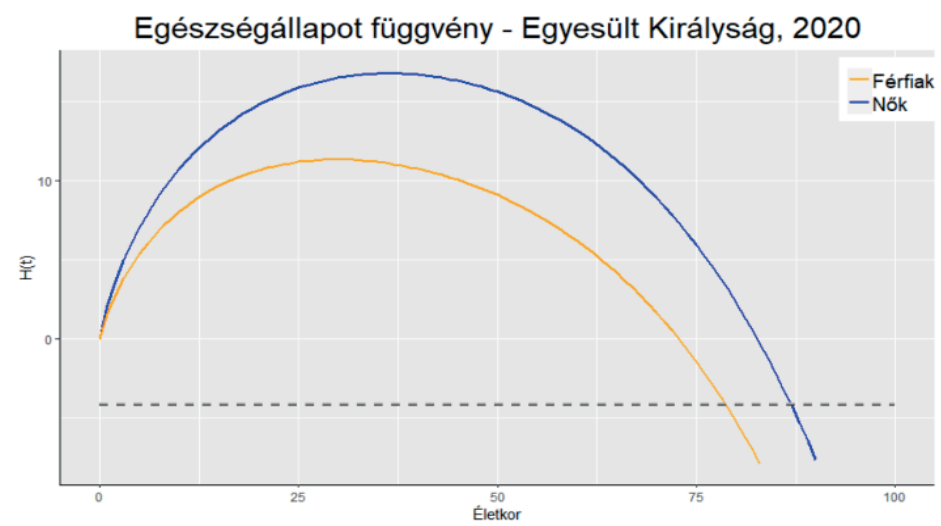

Forrás: saját készités

A nők egészségfüggvénye gyakorlatilag az élettartam folyamán mindig magasabb értéket vesz fel, mint a férfiaké, és később metszi az elérendő $\alpha$ szintet. Az ábrán talán nehezen vehető ki, hogy a férfiakhoz és nőkhöz különböző a szint tartozik, mert a kettő becslése nagyon közel esik egymáshoz (kerekítve nők esetén -4.17, férfiaknál -4.14). Az egyik paraméter, amely értelemszerüen jelezhetné, hogy egy populáció halandósága jobb a másikénál, ha az a szint abszolút értékben nagyobb lenne. Ez most teljesül is a női és férfi lakosság összehasonlításakor, azonban az eltérés mértéke elég kicsi. A kapott paraméterek alapján az egyetlen, ahol nagyobb eltérés van, az a $b$ paraméter. A nők esetében ez nagyobb értéket vesz fel, és ahogy korábban láttuk, ez alacsonyabb becsült rátákat jelent. A nők esetén az átlagos élettartam a becsült rátákkal 81.1 év, a valós rátákkal 80.2 év volt. A férfiak esetén pedig a becsült 75.67 év, a valós 75.38 év volt. Alkalmazzuk azt a modellt is, amikor az egészségállapot függvény alakja:

\section{$H(t)=c-(l t)^{b}$}

ahol $c, b$ és $l$ a becsülendő paraméterek. Ellentétben az előző modellel, ez nem képes kezelni a csecsemőkori halandóságot. Emiatt a modell illesztését nem a teljes élettartamra végezzük el, hanem a kezdeti életkort 30 évnek választjuk meg. Ennek oka a csecsemőkori halandóságon kívül a 17-25 éves kor körüli lakosság kiugróan rosszabb halandósága, a mely többek között a friss jogosítvánnyal rendelkezők magasabb balesetszámának lehet következménye. Most is a brit lakosság adataira végezzük el az illesztést, mégpedig az előzővel ellentétben a likelihood alapú paraméterbecslés segítségével. A 10-11. ábrán láthatóak külön a férfiak és nők esetén a becsült és valós eloszlások: 
10. ábra:
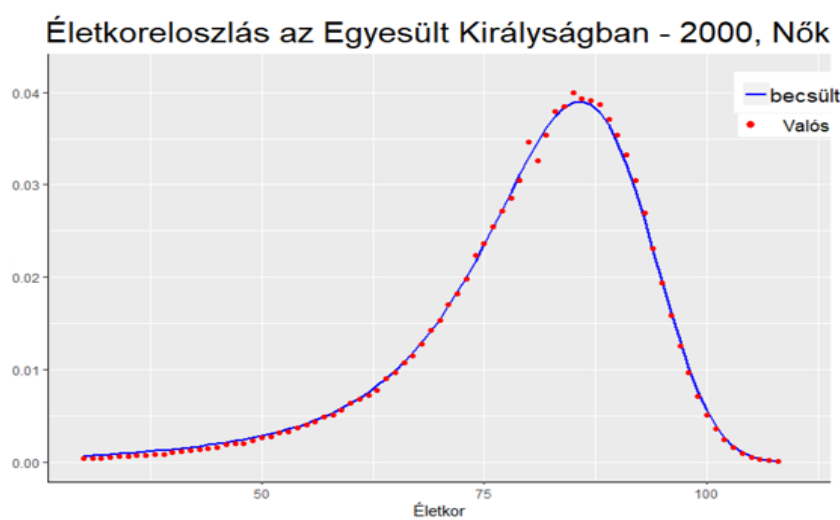

Forrás: saját készités

11. ábra:

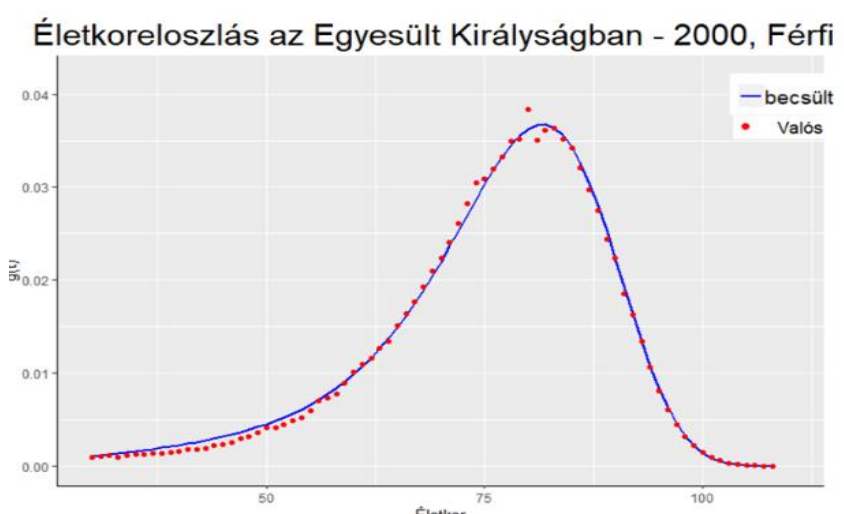

Forrás: saját készités

Az ábrák alapján most is egészen pontos illeszkedést sikerült elérni. A nők lényegesen jobb halandóságát az ábrán kívül a modell paraméterei is jelzik: az egészségállapot függvény c kiindulási szintje magasabb (nők: 20.1, férfiak: 19.4), a b hatványparaméter értéke alacsonyabb (nők: 4.99, férfiak: 4.38) a nők esetén. Az előző modell esetén a halál bekövetkeztének a definíciója az a szint elérése volt. A mostaninál $\alpha=0$. Összehasonlítva, hogy a két modell esetén a $H(t)$ függvény az a szintet melyik kornál éri el először, akkor közel ugyanazt kapjuk: a nők esetén a második modell egyetlen életévvel később lépi át a szintet. A teljesség kedvéért ábrázoljuk a második modell esetén a két egészségállapot függvény alakulását a különböző életkorokra.
12. ábra:

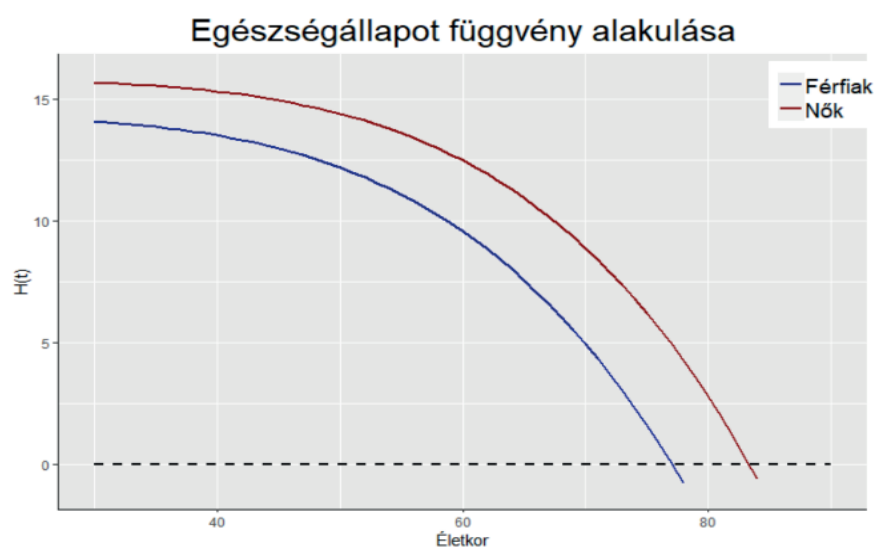

Forrás: saját készités

A cikk további részében az a célunk, hogy a mortalitás alakulását az évek folyamán modellezzük az eddig bemutatott modellek kiterjesztésének segítségével.

\section{Az egészségállapot alakulása}

Az előző pontokban bemutatott modellek jól használhatók voltak egyetlen év adataira való illesztéskor. A következőkben a fö célunk az lesz, hogy a megfigyelt ország halandóságának évtizedek alatti alakulását modellezzük. Elsősorban a svéd lakosság halandóságát fogjuk vizsgálni. Ennek oka az, hogy Svédországból az 1750-es évekig visszamenőleg jó minőségű halandósági adatok állnak rendelkezésre, amelyeken jól lehet modellezni a mortalitás hosszú távú alakulását. A korábban ismertetett modellek közül azt fogjuk alkalmazni, amelyik esetén az egészségállapot függvény paraméterezése a következő:

$$
H(t)=c-(l t)^{b}
$$

ahol $c$, lés $b$ paraméterek. Tegyük fel, hogy rendelkezésre állnak adatok egymást követő naptári évek egy I és életkorok egy $J$ halmazára. Annak érdekében, hogy a halandóság és az egészségállapot függvény változását modellezzük az évek alatt, a paramétereket naptári évekhez és kohorszokhoz rendeljük. A vizsgált $I$ naptári évekhez tartozzon külön-külön más kiindulási szint, azaz egy $c_{i}$ paraméter $(i \in I)$. A kohorszokhoz pedig $l_{i-j}$ legyen a vonatkozó paraméter $(j \in J)$. Vagyis az i-edik naptári évben egy $j$ éves ember egészségállapotát a $c_{i}-\left(l_{i-j} j\right)^{b}$ kifejezés írja le. A $c$ paraméterek tehát egy adott évre jellemző hatásokat hivatottak jellemezni, például ha volt háború vagy komolyabb járvány (például napjainkban a Covid-19 hatása), akkor az évhez tartozó paraméter esetén alacsonyabb 
értéket várnánk. A kohorsz paraméterekben való kiugró változás pedig jelezhet egy-egy generációs hatást. A paramétereket becsüljük maximum-likelihood módszerrel. A maximalizálandó likelihood ekkor

$$
\left.L=\prod_{k \in I} N_{k} ! \prod_{i, j: i-j=k} \frac{g_{k}(j)^{d_{i j}}}{d_{i j} !}\right) \times \frac{\left(1-g_{k}\left(j_{0}\right)-\cdots-g_{k}\left(j_{\max }\right)\right)^{\left(N_{k}-d_{i j_{0}}-\cdots-d_{i j_{\max }}\right)}}{\left(\mathrm{N}_{k}-d_{i j_{0}}-\cdots-d_{i j_{\max }}\right) !}
$$

ahol $k$ a vizsgált kohorszokat jelenti, $N_{k}$ a $k$-adik kohorsz létszáma $j_{0}$ éves korban, $j_{0}$ és $j_{\max }$ a vizsgált minimális és maximális életkor, $g_{k}(j)$ az a valószínűség, hogy a $k$-adik kohorszból egy személy $j$ évesen hal meg, és $d_{i j}$ az $i$-edik évben a $j$ éves korúak halálozási száma. A $g_{k}(j)$ valószínűségeket közelítsük a $H(t)$ egészségállapot függvényből adott $b, c$ és $l$ paraméter esetén becsült értékéből:

$$
g_{k}(j) \approx g(0, t, c, 0)=\frac{\left|c_{i}+(b-1)\left(l_{k} t\right)^{b}\right|}{\sqrt{2 \pi t^{3}}} \exp \left(-\frac{\left(c_{i}-\left(l_{k} t\right)^{b}\right)^{2}}{2 t}\right)
$$

ahol $k=i$ - $j$ továbbra is. Megjegyezzük, hogy egy kohorsz népességszáma nem kizárólag csak a halálozások miatt változhat. Ennek oka lehet az adott országból történő ki-, illetve bevándorlás. Emiatt nem teljesen pontos a fenti likelihood, azonban ezeket a ki- és bevándorlásokat az $N_{k}$ számoknál figelembe vesszük. Természetesen egyszerüsítés az, hogy a bevándorlók halandóságát a kohorsz halandóságával egyezőnek tekintjük. A $b, c_{i}$ és $l_{k}$ paraméterek meghatározása sztochasztikus optimalizálással történt, ugyanis a maximum-likelihood becslést zárt alakban bonyolult lenne felírni. Az optimalizálás folyamatának részletezésétől most eltekintünk, és csak röviden foglaljuk össze. Elöször a paramétereknek olyan kezdeti értékeket adunk, amelyek nagyságrendileg körülbelül megegyeznek a korábban tárgyalt egy évre történő illesztésekkor kapottakkal. Több futtatást végeztünk másik kezdeti értékekkel, de az optimalizálás végeredménye közel ugyanaz lett. Egy iteráción belül elöször megváltoztatjuk egy adott paraméter értékét egy véletlen változóval. Megnézzük, hogy ez a paraméterváltozás mennyire mozdítja el a loglikelihoodot: ha "megfelelő" mértékben és irányban, akkor felülírjuk a paraméter korábbi értékét, ha nem, akkor pedig lépünk a következő paraméterre. Ezt ismételjük egészen addig, amíg a likelihood értéke egy közel állandó értékre beáll, majd további $N$ darab iterációt végzünk, amelyekre átlagolva a paraméterek értékét kapjuk a maximum likelihood becslésként elfogadott paramétereket. Az algoritmus R programcsomag segítségével került implementálásra. Először a svéd nők adataira végeztem el illesztést. Az 1860-2018 közti éveket vettem figyelembe. A vizsgált életkorok 30-tól 90 éves korig voltak. Az optimalizálás során 1650 iteráció történt, és így a becsült $b$ paraméter értéke 4.306-nek adódott, a $c$ kiindulási szint és $l$ paraméterek alakulása az évek során pedig a 13.-14- ábrákon látható: 
maradnia a háború jelentős részében. Ezt magyarázva inkább a spanyol nátha hatására ismerhetünk rá. A cikk elején említettük, hogy az angolszász országokban a 2010-es években a halandóság javulása megállt, sőt kismértékben romlani kezdett. A modellünk becsült $c$ paramétereit alapul véve, a svéd nők esetén az mondható el, hogy a halandóság javulásának üteme itt is lassulni kezd. A kohorszokra jellemző $l$ paraméterek esetén 1900-1980-ig egy trendszerü csökkenést figyelhetünk meg, de kiugró értéket nem látunk. A 15. ábrán négy kohorszra ábrázoljuk, hogy a becsült életkoreloszlása a kohorszoknak mennyire illeszkedik jól a valós adatokra.

\section{5. ábra: A svéd nők négy kohorszának életkoreloszlása}
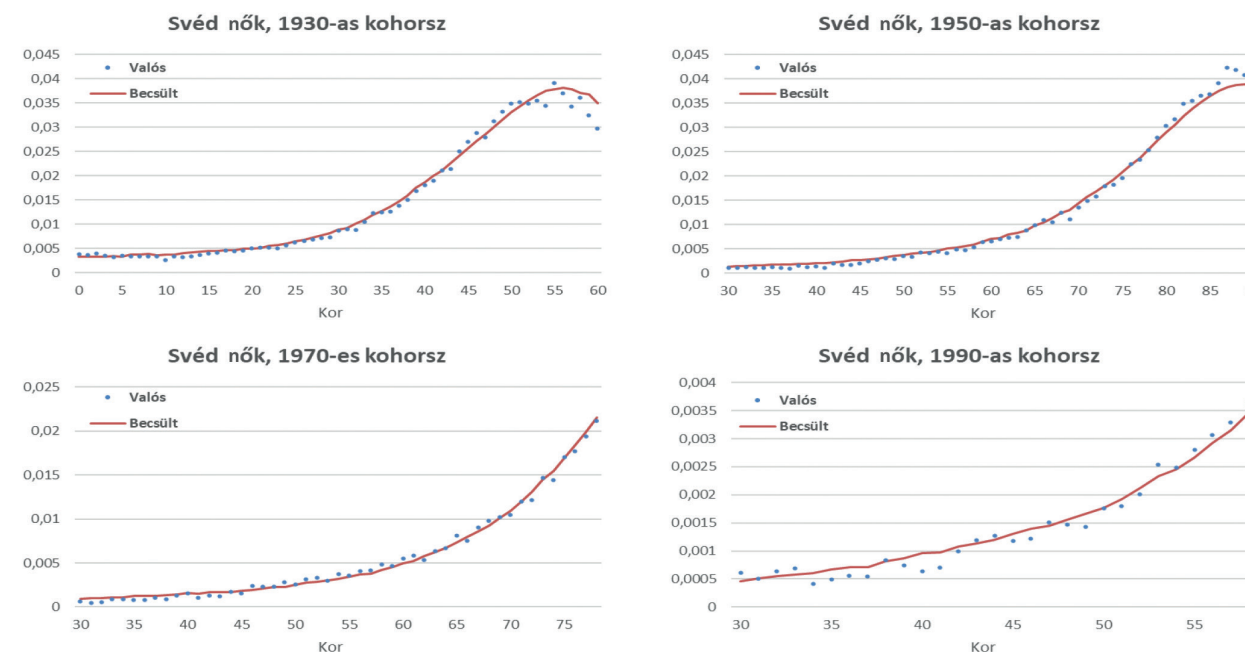

Forrás: saját készités

Egy másik ellenőrzés az illeszkedés minőségére, ha összehasonlítjuk egy adott évben minden életkorra az egy éven belüli halálozási valószínűségeket ( $q_{x}$-eknek megfelelő ráták) a becsült és valós esetben. Ezek szemléltetésére készültek a 16. ábra alábrái.

\section{6. ábra: A svéd nők négy kohorszának éven belüli halandósága}
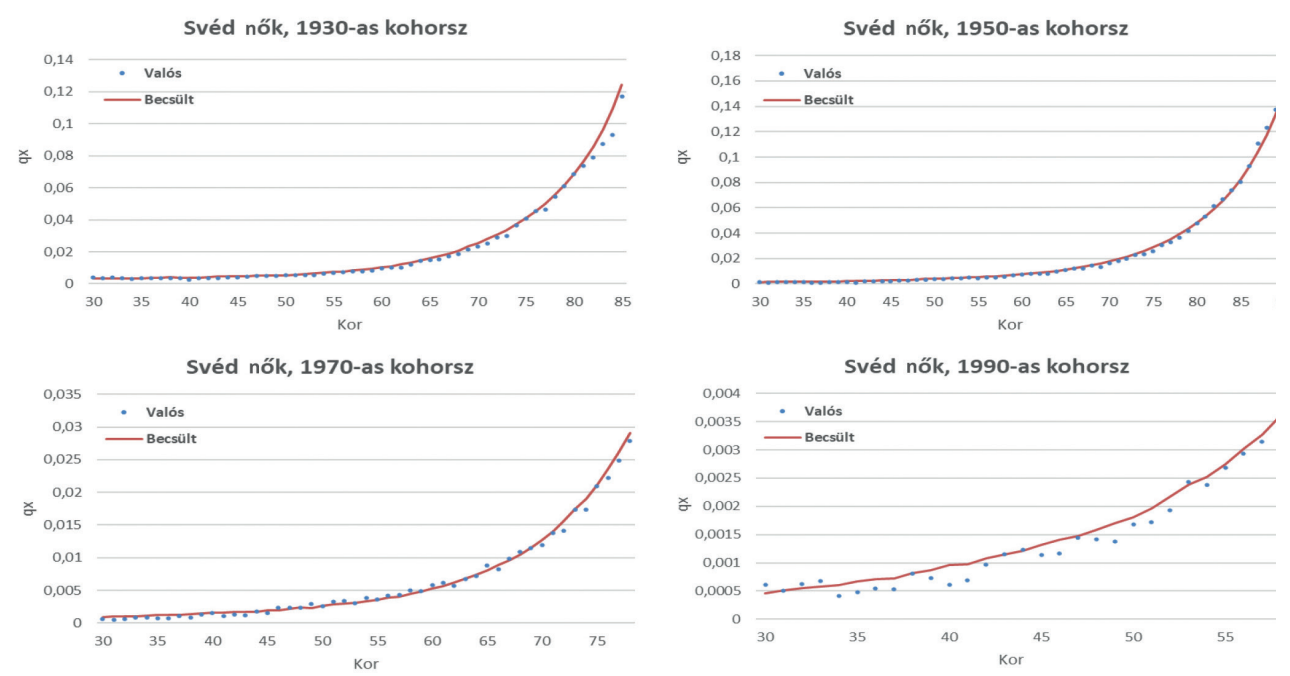

Forrás: saját készités

\section{Elörejelzés}

Az utóbbi évtizedekre a halandóság javulása jellemző a Föld országainak többségében. Az életbiztosításban és a nyugdíjbiztosításban is egyre jelentősebb a hosszú élet kockázata, azaz hogy az emberek egyre nagyobb valószínüséggel élnek kimagaslóan hosszú évekig. A következő részben a célunk az, hogy az előzőekben ismertetett modell segítségével előre jelezzük a halandóság alakulását. Példaként továbbra is a svéd nők adatait tekintjük. Az alapvető koncepció az, hogy a paraméterek időbeli alakulását jelezzük elöre, majd azok segítségével számoljuk a különböző kohorszok mortalitásának alakulását az évek során. Az előző részben maximum likelihood módszerrel becsültük a paramétereket, a $c$ paraméterek az 1860-2018-as naptári évekhez, az l paraméterek az 1840-1998-as születési évekhez tartoztak. Ezen paraméterek becslése későbbi évekre úgy történjen, hogy tekintsünk rájuk független idősorokként, és illesszünk rájuk ARIMA modellt. A c paraméterek esetén először ahelyett, hogy 1860-tól tekintettük volna az idősort, csak az elmúlt 100 évre illesztettünk modellt. Ennek oka egyrészt az, hogy a korábbi évekhez tartozó becslések relatíve kevés megfigyelés alapján történtek, másrészt kellően régen voltak ahhoz, hogy ne vegyük figyelembe őket a 2015 utáni évek becsléséhez. Végeztünk becslést úgy is, hogy csak az utolsó 35 év adatai alapján jeleztünk előre. Az l paraméterek esetén pedig az utolsó, későbbi évekhez tartozó paraméterek becslése történt kevés megfigyelés alapján, és eléggé ingadozó becsléseket kaptunk. Ezért az 1960-1998-as születési éveknek megfelelő $l$ paramétereket nem tekintettük az 
ARIMA modell illesztésekor. Továbbá az előző alfejezetben azt láttuk, hogy körülbelül az 1880 -as születési évek legelejétől folyamatosan csökken a paraméter értéke időben, előtte pedig jellemzően nőtt, ezért illesztettünk úgy is idősoros modellt, hogy az első 40 évet belevettük, és úgy is, hogy kihagytuk. A $c$ és $l$ paraméterek alakulásának becslése ezeknek az idősoroknak az elörejelzésével történik. Az elörejelzést, a 80\% és 90\% konfidencia intervallumokat a 17. ábra négy alábráján szemléltetjük.

\section{7. ábra: A c és 1 paraméterek alakulásának a becslése}
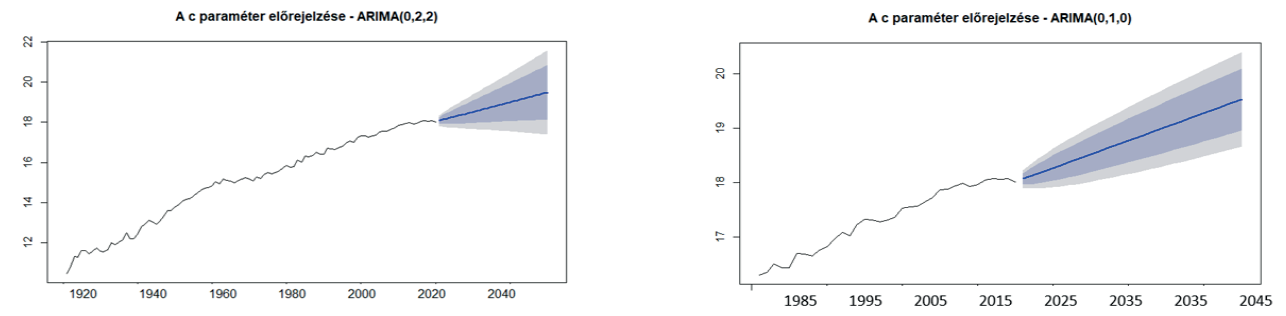

Azl paraméter elörejelzzése -ARIMA(0,23)
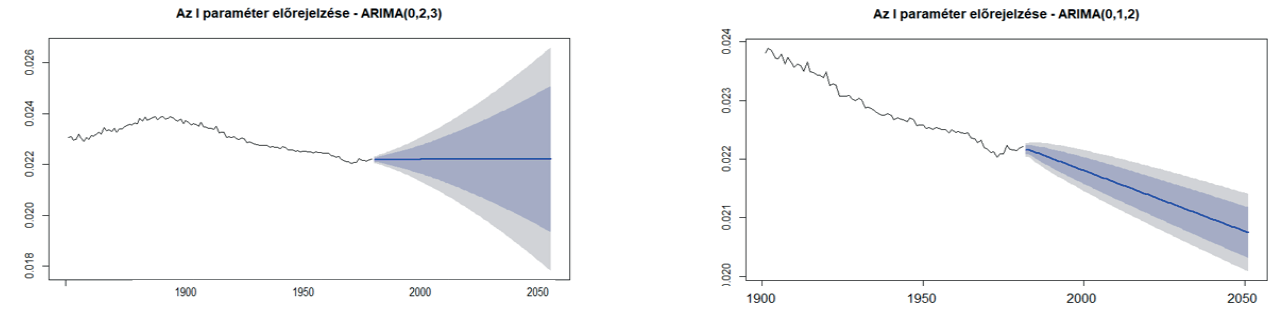

Forrás: saját készités

A következőkben nézzük meg, hogy néhány kohorsz esetén ezek az előrejelzett paraméterek milyen "életkoreloszlást" eredményeznek. Az első esetben tekintsük azt, amikor a $c$ és az $l$ paraméterek becslése is a tágabb idősor alapján történik, a második esetben pedig, amikor kevesebb becsült paraméterre illesztünk. Az eredményeket a 18-19. ábrákon szemléltetjük (az első ábrán az első esethez tartozó, a másodikon a másodikhoz tartozó becslés szerepel):
18. ábra:

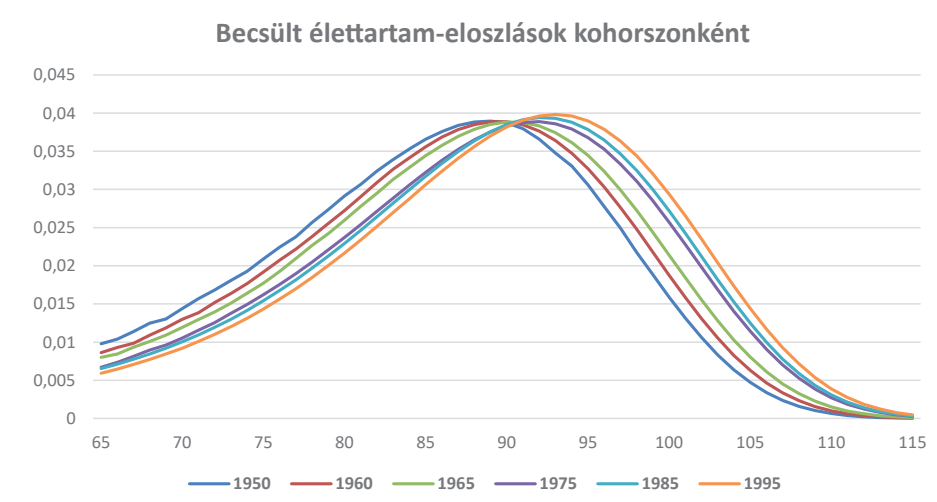

Forrás: saját készités

19. ábra:

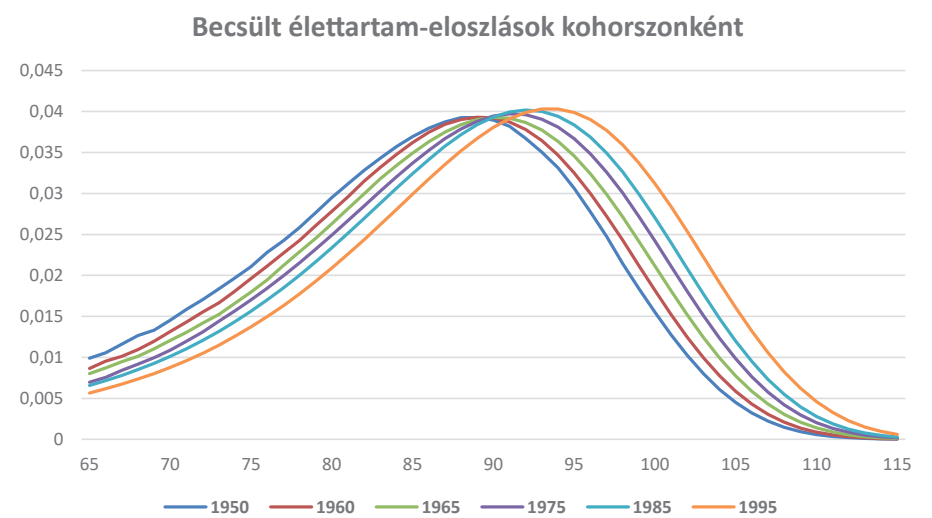

Forrás: saját készités

Az idő előrehaladtával a kohorszok mortalitása fokozatosan javul az ábra alapján, ugyanis a későbbi kohorszok esetén egyre nagyobb valószínűséggel fordulnak elő idősebb korok. Ez a halandóság általános javulásának megfelelő eredmény, és erre is számítottunk, lévén hogy a $c$ paraméterek folyamatos emelkedését jeleztük előre. Nyugdíjjárulékok esetén például fontos mutatószám lehet a nyugdíjban töltött évek várható száma. A 65 év felettiek várható élettartama az adott kohorszra jellemző $g$ élettartam "eloszlás" sűrűségfüggvénnyel felírva:

$$
\int_{65}^{110} s g(s) / p_{65} d s \approx \sum_{s=65}^{110} g(s) s / p_{65}
$$


ahol $p_{65}$ jelöli azt a valószínűséget, hogy egy személy megéli a 65 éves kort. Az első becslés alapján kapott várható élettartamát egy 65 évet megélt svéd nőnek az 1. táblázat tartalmazza:

\section{1. táblázat}

\begin{tabular}{ccccccc} 
Születési év & 1930 & 1940 & 1945 & 1955 & 1965 & 1975 \\
\hline Várható élettartam & 86.5 & 87.3 & 88.1 & 88.9 & 89.2 & 89.7
\end{tabular}

Forrás: saját készités

A második becslés alapján kapott eredményeket pedig a 2. táblázat foglalja össze:

2. táblázat

\begin{tabular}{ccccccc} 
Születési év & 1930 & 1940 & 1945 & 1955 & 1965 & 1975 \\
\hline Várható élettartam & 86.5 & 87.3 & 88.1 & 89.0 & 89.7 & 91.0
\end{tabular}

Forrás: saját készités

A becsült várható élettartamok a későbbi kohorszok esetén nagyobb eltérést mutatnak a két becslés során. Az előző esetekben a $c$ paramétereket az elmúlt 100 és 35 év alapján jeleztük elöre. Azonban a paraméterek utolsó 10 évhez tartozó értéke közel állandó volt, nem volt jellemző a korábbi fokozatos növekedés. Készítettünk úgy is egy előrejelzést, hogy a c paraméter értéke a 2018 utáni években konstans, és az utolsó 10 megfigyelt évhez tartozó átlagos paraméterértéket veszi fel (az $l$ paraméter pedig a hosszabb időtartam alapján elörejelzett értékeket vegye fel). Az így kapott várható élettartamot a 65 évet megélt svéd nők esetén a vizsgált kohorszokban a 3. táblázat foglalja össze:

\section{3. táblázat}

\begin{tabular}{ccccccc} 
Születési év & 1930 & 1940 & 1945 & 1955 & 1965 & 1975 \\
\hline Várható élettartam & 86.3 & 86.9 & 875 & 88.1 & 88.0 & 87.9
\end{tabular}

Forrás: saját készités

A várható élettartam tehát a későbbi kohorszok esetén közel állandó a becslések alapján, sőt enyhén csökken. Összehasonlításképpen megnéztem a hivatalos svéd statisztikai hivatal (Statistika centralbyran, SCB, [7]) által közzétett várható élettartamot 65 éves korban a vizsgált kohorszok esetén (4. táblázat):
4. táblázat

\begin{tabular}{ccccccc} 
Születési év & 1930 & 1940 & 1945 & 1955 & 1965 & 1975 \\
\hline Várható élettartam & 84.9 & 85.6 & 86.1 & 87 & - & -
\end{tabular}

Forrás: saját készités

Ezek alapján a modelljeinkkel felülbecsüljük a 65 éves kori várható élettartamot. Ennek oka lehet, hogy modelljeink esetén pozitív a valószínüsége annak is, hogy egy személy akár 115 éves korig éljen, míg más modellek esetén ez nem feltétlen van így, és egy maximális élettartamot határoz meg 100 vagy 110 éves kornál.

\section{Összegzés}

A szakdolgozatom egy adott populáció halandóságának dinamikus modellezése volt. Bemutatásra került egy Skiadas és Janssen nevéhez köthető sztochasztikus halandósági modell, amelynek alapvető szemlélete az, hogy az egyének egészségi állapotának alakulását és halandóságát kapcsolja össze. Bevezetésre került az "egészségállapot függvény", amely egy lakosság átlagos egészségi helyzetét hivatott jellemezni különböző korcsoportokra. A modell kiegészítésével a halandóság alakulását tudjuk modellezni több egymást követő naptári év folyamán, figyelembe véve az egyes kohorszokra jellemző hatásokat. Több ország valós mortalitási adataira illesztettük a modelljeinket. Először brit nők és férfiak élettartam-eloszlásait hasonlítottuk össze 30 éves kor felett (a 2000-es év adatai alapján). A pontos illeszkedés mellett visszakaptuk azt a tényt, hogy a női lakosság halandósága (és egészségi állapota) lényegesen jobb a férfi lakosságénál. Svédország, az Egyesült Államok és az Egyesült Királyság női lakosságának esetén modelleztük a halandóság alakulását. A Human Mortality Database adatbázisból több évtizedre visszamenőleg érhetők el ezekre az országokra mortalitási adatok (a svédek esetén egészen a 18. század második feléig), amelyek alapján hosszabb távú előrejelzést is adtunk. Az előrejelzés ARIMA idősoros modellekkel történt. Az angolszász országok esetében az utóbbi évtizedben jelentkező halandóságromlást sikerült modellezni az egészségfüggvény becsült paraméterei révén. Természetesen nagyon sok mindent nem végeztünk el a szakdolgozatban, de az mindenképpen túllépett volna az adott munka keretein. A teljesség igénye nélkül felsorolunk néhány témát, amelyet a későbbiekben érdemes lenne vizsgálni.

- A becslési eljárások és előrejelzések összehasonlítása más nevezetes, általánosan használt modellekkel (például Lee-Carter);

- A paraméterek összefüggései az országra jellemző indikátorokkal;

- Járványok, Covid-19 hatása az elörejelzésre.

Munkánkban mi „csak” egy konkrét modellt vizsgáltunk meg, és azt próbáltuk továbbfejleszteni. Skiadas és szerzőtársai munkáihoz képest legalább két területen sikerült új eredményt elérni. Egyrészt a paraméterek becslését maximum likelihood módszerrel is elvégeztük, 
másrészt a sokkal természetesebb kohorsz alapú modellt is felépítettük. Ez a későbbiekben felhasználható lenne előrejelzésekhez is (ennek kezdeti lépéseit be is mutattuk). További vizsgálatként érdemes lehet összevetni, hogy ezzel a dinamikus halandóság-elörejelzéssel kapott díjak mennyire térnek el a statikus halandósági táblák segítségével számolt díjaktól különböző járadéktermékek esetén. Ehhez hasonló munkát végzett Gogola és Vékás [15], akik Lee-Carter alapú előrejelzéseket használnak.

\section{IRODALOMJEGYZÉK}

[1] J. Janssen, C. H. Skiadas, Dynamic modelling of life table data, Applied Stochastic Models and Data Analysis,11, 1995.

[2] C.H. Skiadas, C. Skiadas, Exploring the health state of a population by dynamic modeling methods, The Springer Series on Demographic Methods and Population Analysis, 2018

[3] C.H. Skiadas, A modeling approach to life table datasets, Recent Advances in Stochastic Modeling and Data Analysis, 2007.

(1)

4] C.H. Skiadas, C. Skiadas, Exploring the state of a stochastic system via stochastic Simulations: An interesting inversion problem [5] N. G. van Kampen, Stohastic processes in physics and chemistry, North-Holland Personal Library, 2007, 73-95 C. W. Gardiner, Handbook of Stochastic Methods, Springer, 2009.

[6] Sved Statisztikai Hivatal adatal, 2020, https://www.scb.se/en/finding-statistics/statistics-by-subject-area/population/populationcomposition/population-statistics/pong/tables-and-graphs/yearly-statistics-the-whole-country/life-expectancy/
letölés sdeje: 2021 -

töltés ideje: 2021.04.10.

[8] C. . Gever, Markov Chain Monte Carlo Mwaximum likelihood Schooltés ideje: 2021.04 .10

[10] L. Caroll, U.S. life expectancy declining due to more deaths in middle age, Reuters, 2019

[11] N. Ouellette, M. Barbieri, J. R. Wilmoth, Mortality and life expectancy trends in the UK: stalling progress, The Health Foundation, 2019, [12] L. Marshall, D. Finch, L. Cairncross, J. Bibby, Period-Based Mortality Change: Turning Points in Trends since 1950, Population

[13] Hegel P., Halandóśág becslése az egészségállapot függvény segítségével (szakdolgozat), 2020, https://web.cs.elte.hu/blobs/ Letöltés ideje: 2021.04.10.

[14] Horvath Gy., Fordulat a halandóságban?, Biztositás és kockázat, 2019. 3. szám

https://mabisz.hu/wp-content/uploads/2019/10/biztositas-es-kockazat-6-evf-3-szam-2-cikk.pdf Letöltés: 2021.04.10

[15] Gogla J Véḱ́s P. Élettartam-koctaz

https://mabisz hu/wp-content/uploads/2020/11/biztositas-es-kockagyarországon, Biztositás és kocḱázat, 2020. 3. szám 